\title{
PENTINGNYA KETEPATAN DIAGNOSA KEPERAWATAN \\ TERHADAP KELANCARAN ASUHAN KEPERAWATAN
}

\author{
Novi Pratiwi \\ novipratiwi211@gmail.com
}

\section{Latar Belakang}

Standar praktek keperawatan profesional mengacu pada standar asuhan keperawatan dan standar kinerja profesional perawat. Perawat dalam melaksanakan asuhan keperawatan harus sesuai dengan standar asuhan keperawatan yang ada. Standar asuhan keperawatan meliputi lima komponen penting yaitu, Pengkajian Keperawatan, Diagnosis Keperawatan, Perencanaan (Intervensi), Pelaksanaan (Implementasi) dan Evaluasi. Keberhasilan suatu asuhan keperawatan kepada pasien sangat ditentukan oleh pemilihan metode pemberian asuhan keperawatan professional.

Salah satu kompetensi perawat adalah mampu merumuskan diagnosa keperawatan yang baik dan benar, dimana diagnosa keperawatan merupakan kesimpulan yang dihasilkan dari analisis data, sehingga menghasilkan pernyataan yang jelas, singkat dan pasti tentang masalah kesehatan pasien. Melalui diagnosa yang tepat tersebut, pasien dapat menerima informasi dan penjelasan yang tepat tentang masalah kesehatan yang dialami pasien.

Dalam proses menjalankan tugas sebagai pemberi asuhan keperawatan, perawat berwenang untuk menegakkan diagnosis keperawatan (Pasal 30 UU No.38 tahun 2014). Pada kegiatan analisis data dalam perumusan diagnosa keperawatan, diperlukan kemampuan kognitif dalam pengembangan daya berfikir dan penalaran yang dipengaruhi oleh latar belakang ilmu dan pengetahuan yang dimiliki seorang perawat. Analisis data dalam perumusan diagnosa keperawatan dimulai dengan pengelompokan data yang diperoleh dari anamnesa, pengamatan dan pemeriksaan fisik lalu hasil yang didapat dibandingkan dengan standar (kondisi normal), sehingga dapat diketahui permasalahan kesehatan yang dialami pasien dan dapat dirumuskan masalah kesehatan pasien.

Sering sekali perawat kesulitan dalam menentukan diagnosis keperawatan spesifik yang dialami oleh pasien. Hal ini mungkin karena pengkajian keperawatan yang tidak terstruktur dengan baik. Pengkajian yang dilakukan oleh perawat tidak mempunyai urutan yang runut dan 
terkait dengan diagnosis keperawatan. Sering terjadi bahwa perawat mempunyai data tertentu tetapi kebingungan untuk menentukan data tersebut mendukung diagnosis keperawatan yang mana. Atau sebaliknya perawat mempunyai prediksi pasien mempunyai diagnosis tertentu tetapi tidak tahu data apa yang perlu dikaji untuk mendukung diagnosis tersebut muncul.

Berdasarkan uraian latar belakang tersebut perawat dalam melaksanakan asuhan keperawatan harus memperhatikan standar asuhan keperawatan yang ada. Dengan adanya ketepatan diagnosa keperawatan oleh perawat, tentunya akan menjadi lebih mudah untuk mengarahkan dan memfokuskan dalam meningkatkan mutu asuhan keperawatan.

\section{Metode}

Metode yang dilakukan dalam penulisan ini adalah metode kepustakaan yaitu dengan mengumpulkan data-data yang diperoleh dari buku dan jurnal-jurnal terkini kemudian menganalisis data-data tersebut untuk menentukan tindakan perawat yang tepat dalam melakukan diagnosa keperawatan agar tercapainya keberhasilan atau kelancaran asuhan keperawatan.

\section{Hasil}

Proses asuhan keperawatan merupakan tugas dan kewajiban seorang perawat dari pasien datang sampai pasien pulang, dimulai dengan pengkajian secara menyeluruh, kemudian menegakkan diagnosa keperawatan dari data pengkajian tersebut, serta melaksanakan intervensi, implementasi dan evaluasi keefektifan diagnosa awal yang sudah ditegakkan.

Diagnosis Keperawatan merupakan keputusan klinik tentang respon individu, keluarga dan masyarakat tentang masalah kesehatan aktual atau potensial, dimana berdasarkan pendidikan dan pengalamannya, perawat secara akuntabilitas dapat mengidentifikasi dan memberikan intervensi secara pasti untuk menjaga, menurunkan, membatasi, mencegah dan merubah status kesehatan klien.

Ketepatan melakukan diagnosa menjadi langkah awal dalam sebuah proses pengobatan karena ketepatan dalam melakukan diagnosa maka akan mempengaruhi tindakan yang akan dilakukan selanjutnya. Diagnosa juga meliputi penentuan kebutuhan pasien untuk perawatan seperti dukungan, bimbingan, jaminan, pendidikan, pelatihan, dan perawatan lainnya yang memfasilitasi kemampuan pasien untuk mencari perawatan. 
Ketepatan merupakan seberapa jauh perilaku seseorang dalam hal penggunaan obat, mengikuti diet atau mengubah gaya hidup sesuai dengan nasehat medis atau saran kesehatan sehingga tidak terjadi hal yang membahayakan hasil terapi pasien.

Di Instalasi Gawat Darurat (IGD) pengetahuan dan keterampilan perawat sangat dibutuhkan, terutama dalam pengambilan keputusan klinis keterampilan penting bagi perawat dalam penilaian awal. Perawat harus mampu memprioritaskan perawatan pasien berdasarkan pengambilan keputusan yang tepat. Untuk mendukung hal tersebut diperlukan pengetahuan dan keterampilan khusus dalam pemisahan jenis dan kegawatan pasien dalam triage, sehingga dalam penanganan pasien bisa lebih optimal dan terarah serta asuhan keperawatan dapat tercapai dengan baik.

Proses mengkaji dan mendiagnosis merupakan kegiatan yang sangat penting karena menentukan keberhasilan asuhan keperawatan. Dalam merumuskan diagnosis keperawatan terdapat beberapa kegiatan yang dilakukan dalam mendiagnosis keperawatan yaitu interpretasi dari data yang ada, kemudian melakukan verifikasi dengan pasien, menentukan label diagnosis keperawatan dan menuliskan diagnosis keperawatan. Pada saat perumusan diagnosa keperawatan membutuhkan proses berpikir kritis, keterampilan penalaran dan pengalaman sebelumnya.

\section{Pembahasan}

Diagnosa keperawatan merupakan tahap kedua dalam proses keperawatan setelah melakukan pengkajian keperawatan dan pengumpulan data hasil pengkajian. Diagnosa keperawatan merupakan penilaian klinis tentang respons individu, keluarga, atau komunitas terhadap masalah kesehatan atau proses kehidupan aktual ataupun potensial sebagai dasar pemilihan intervensi keperawatan untuk mencapai hasil tempat perawat bertanggung jawab. Komponen diagnosa keperawatan menurut PPNI terdiri dari masalah (P), etiologi atau penyebab (E) dan tanda atau gejala (S), atau terdiri dari masalah dengan penyebab (PE).

Tujuan diagnosis keperawatan adalah perawat untuk menganalisis dan mensintesis data yang telah dikelompokkan, selain itu diagnosis keperawatan digunakan untuk mengidentifikasi masalah, faktor penyebab masalah, dan kemampuan klien untuk dapat mencegah atau memecahkan masalah tersebut.

Beberapa bentuk pernyataan diagnosa keperawatan yaitu:

1. Diagnosa yang bersifat aktual 
Diagnosis keperawatan aktual adalah diagnosis yang menjelaskan masalah yang nyata terjadi saat ini.

Contoh diagnosa keperawatan aktual:

\begin{tabular}{|l|l|c|}
\hline \multicolumn{1}{|c|}{ Tanggal / jam } & \multicolumn{1}{|c|}{ Diagnosis keperawatan } & Paraf \\
\hline 02-07-2019 / 08.00 & $\begin{array}{l}\text { Diare yang berhubungan dengan } \\
\text { WIB }\end{array}$ & Ny. C \\
& $\begin{array}{l}\text { ditandai dengan BAB cair, ada } \\
\text { ampas 8x/hari }\end{array}$ & \\
\hline
\end{tabular}

2. Diagnosis keperawatan risiko/risisko tinggi

Diagnosis keperawatan risiko/risiko tinggi adalah keputusan klinis bahwa individu, keluarga/komunitas sangat rentan untuk mengalami masalah dibandingkan yang lain pada situasi yang sama atau hampir sama.

Contoh diagnosa keperawatan risiko:

\begin{tabular}{|l|l|c|}
\hline \multicolumn{1}{|c|}{ Tanggal / jam } & \multicolumn{1}{|c|}{ Diagnosis keperawatan } & Paraf \\
\hline $\begin{array}{l}\text { 02-07-2019 / 09.00 } \\
\text { WIB }\end{array}$ & $\begin{array}{l}\text { Risiko konstipasi yang } \\
\text { berhubungan dengan diet rendah } \\
\text { serat }\end{array}$ & Ny. S \\
\hline
\end{tabular}

3. Diagnosis keperawatan kemungkinan.

Diagnosis keperawatan kemungkinan merupakan pertanyaan tentang masalah yang diduga akan terjadi atau masih memerlukan data tambahan.

Contoh:

\begin{tabular}{|l|l|c|}
\hline \multicolumn{1}{|c|}{ Tanggal / jam } & \multicolumn{1}{|c|}{ Diagnosis keperawatan } & Paraf \\
\hline $\begin{array}{l}\text { 02-07-2019 / 09.00 } \\
\text { WIB }\end{array}$ & $\begin{array}{l}\text { Kemungkinan konstipasi yang } \\
\text { berhubungan dengan bed rest }\end{array}$ & Ny. S \\
\hline
\end{tabular}

4. Diagnosis keperawatan sejahtera

Diagnosis keperawatan sejahtera/positif merupakan keputusan klinis yang divalidasi oleh ungkapan subjektif yang positif ketika pola fungsi dalam keadaan efektif. Keputusan klinis tentang keadaan individu, keluarga, atau masyarakat dalam transisi dari tingkat sejahtera tertentu ke tingkat sejahtera yang lebih tinggi. 
Contoh:

\begin{tabular}{|l|l|c|}
\hline \multicolumn{1}{|c|}{ Tanggal / jam } & \multicolumn{1}{|c|}{ Diagnosis keperawatan } & Paraf \\
\hline $\begin{array}{l}\text { 02-07-2019 / 10.00 } \\
\text { WIB }\end{array}$ & $\begin{array}{l}\text { Potensial terhadap peningkatan } \\
\text { peran menjadi orang tua }\end{array}$ & Ny. S \\
\hline
\end{tabular}

Adapun langkah-langkah dalam menentukan diagnosa keperawatan yaitu:

1. Perawat harus melakukan klasifikasi data. Klasifikasi data adalah aktivitas pengelompokan data-data klien atau keadaan tertentu tempat klien mengalami permasalahan kesehatan atau keperawatan berdasarkan kriteria permasalahannya. Klasifikasi ini berdasarkan pada kebutuhan dasar manusia yang dikelompokkan dalam data subjektif dan data objektif.

2. Perawat harus membuat interpretasi data, yaitu membuat interpretasi atas data yang sudah dikelompokkan dalam bentuk masalah keperawatan atau masalah kolaboratif.

3. Perawat harus menentukan hubungan sebab-akibat. Dari masalah keperawatan yang telah ditentukan, perawat harus menentukan faktor-faktor yang berhubungan atau faktor risiko yang menjadi kemungkinan penyebab dari masalah yang terjadi. Kemungkinan penyebab harus mengacu pola kelompok data yang sudah ada.

4. Perawat harus merumuskan diagnosis keperawatan. Perumusan diagnosis keperawatan tersebut didasarkan pada pola identifikasi masalah dan kemungkinan penyebab.

Diagnosis keperawatan melibatkan proses berpikir kompleks tentang data yang dikumpulkan dari klien, keluarga, rekan medis dan pemberi pelayanan kesehatan yang lain. Untuk dapat merumuskan diagnosa keperawatan dibutuhkan kemampuan analisis yang tinggi sehingga diperlukan sumber daya manusia yang capable dan mempunyai motivasi kuat untuk maju serta berpandangan maju (futuristic).

Penelitian menunjukkan bahwa pada status pasien yang telah dikaji terlihat bahwa perawat hanya memilih saja diagnosa keperawatan yang telah disediakan di bagian samping format pengkajian. Hal ini memang lebih memudahkan perawat akan tetapi juga dapat menyebabkan perawat menjadi malas dan kurang inisiatif untuk menganalisa data lalu merumuskan diagnosa keperawatan sendiri apabila ditemukan data yang berbeda. Kondisi demikian juga menimbulkan kualitas pendokumentasian diagnosa keperawatan menjadi monoton. 
Semua data yang ditampilkan pada setiap diagnosis keperawatan mencakup hal-hal berikut ini:

a. Definisi. Merujuk kepada definisi NANDA yang digunakan pada diagnosis-diagnosis keperawatan yang telah ditetapkan.

b. Kemungkinan etiologi. Bagian ini menyatakan penyebab-penyebab yang mungkin untuk masalah yang telah diidentifikasi. Yang tidak dinyatakan oleh NANDA diberi tanda kurung. Faktor yang berhubungan/risiko diberikan untuk diagnosis yang beresiko tinggi.

c. Batasan karakteristik. Bagian ini mencakup tanda dan gejala yang cukup jelas mengidentifikasikan keberadaan suatu masalah.

d. Sasaran/tujuan. Pernyataan-pernyataan ini ditulis sesuai dengan objektif perilaku klien. Sasaran/tujuan ini harus dapat diukur, merupakan tujuan jangka panjang dan pendek, untuk digunakan dalam mengevaluasi efektivitas intervensi keperawatan dalam mengatasi masalah yang telah diidentifikasi.

e. Mungkin akan ada lebih dari satu tujuan jangka pendek dan mungkin merupakan "batu loncatan" untuk memenuhi tujuan jangka panjang.

f. Intervensi dengan rasional tertentu. Hanya intervensi-intervensi yang sesuai untuk bagian diagnosis yang dapat ditampilkan.

g. Hasil klien yang diharapkan/kriteria pulan. Perubahan perilaku sesuai dengan kesiapan klien untuk pulang yang mu ngkin untuk dievaluasi.

h. Informasi mengenai obat-obatan. Informasi ini mencakup implikasi keperawatan.

\section{Penutup}

Diagnosa keperawatan merupakan keputusan klinik yang mencakup klien, keluarga dan respons komunitas terhadap sesuatu yang berpotensi sebagai masalah kesehatan dalam proses kehidupan. Salah satu manfaat dari diagnosis keperawatan adalah memberikan gambaran tentang masalah atau status kesehatan klien yang nyata (aktual) dan kemungkinan akan terjadi, dimana pemecahannya dapat dilakukan batas wewenang perawat. Diagnosis keperawatan ditetapkan berdasarkan analisis dan interpretasi mendalam terhadap data yang diperoleh perawat dari pengkajian keperawatan klien. Ketepatan dalam menentukan diagnosa keperawatan tentunya akan menjadi lebih mudah untuk mengarahkan dan memfokuskan dalam meningkatkan mutu asuhan keperawatan. 
Maka perlu diadakan pelatihan tentang asuhan keperawatan sehingga perawat nantinya mampu meningkatkan asuhan keperawatan dengan baik dan benar mulai dari pengkajian menyeluruh, menentukan diagnosa keperawatan, hingga evaluasi.

\section{Daftar Pustaka}

Amri, A., Manjas, M., \& Hardisman. (2019). Analisis implementasi triage, ketepatan diagnosa awal dengan lama waktu rawatan pasien di RSUD Prof. DR. MA Hanafiah SM Batusangkar. Jurnal Kesehatan Andalas, 8(3), 484-492.

Apriyani, H. (2015). Identifikasi diagnosis keperawatan pada pasien di ruang paru rumah sakit. Jurnal Keperawatan, 11(1), 107-111.

Budiono, Sumirah B. P. (2015). Konsep dasar keperawatan. Jakarta: Bumi Medika.

Dermawan, D. (2012). Proses keperawatan: Penerapan konsep \& kerangka kerja. Yogyakarta: Gosyen.

Ermayani, M. \& Nuryanti, A. (2017). Pengembangan format dokumentasi asuhan keperawatan berbasis SNL NANDA-I, NOC, dan NIC di ruang rawat inap. Mahakam Nursing Journal, 2(2), 50-61.

Muhith, A., Rizqina, R., Zulailah, D. (2019). Hubungan budaya organisasi terhadap mutu asuhan keperawatan. Jurnal Ilmiah Ilmu Kesehatan, 7(3), 149-157.

Rofi'i, M., Warsito, B. E., Santoso, A., \& Ulliya, S. (2018). Diagnosa keperawatan yang sering ditegakkan perawat pada pasien tuberkulosis paru di rumah sakit. Jurnal Kepemimpinan dan Manajemen Keperawatan, 1(2), 1-8.

Simamora, R. H. (2019). Socialization of Information Technology Utilization and Knowledge of Information System Effectiveness at Hospital Nurses in Medan, North Sumatra. Editorial Preface From the Desk of Managing Editor..., 10(9).

Simamora, R. H., Bukit, E., Purba, J. M., \& Siahaan, J. (2017). Penguatan kinerja perawat dalam pemberian asuhan keperawatan melalui pelatihan ronde keperawatan di rumah sakit royal prima medan. Jurnal pengabdian kepada masyarakat, 23(2), 300-304.

Sumaryati, M. (2018). Studi kasus asuhan keperawatan gerontik pada keluarga Ny. M dengan hipertensi di kelurahan barombong kecamatan tamalate kota makassar. Jurnal Ilmiah Kesehatan Sandi Husada, 6(2), 1379-1383. 
Supratti \& Ashriady. (2016). Pendokumentasian asuhan keperawatan di RSUD Mamuju, Indonesia. Jurnal Kesehatan Manarang, 2(1), 44-51.

Utami, N. W., dkk. (2016). Etika keperawatan dan keperawatan profesional. Jakarta: Pusdik SDM Kesehatan.

Wulandini, P., Krianto, T., \& Priwahyuni, Y. (2016). Faktor-faktor yang berhubungan dengan pendokumentasian asuhan keperawatan di RSJ. Ners Jurnal Keperawatan, 12(2), 131-142. 